\title{
Emphysematous pyelonephritis in a diabetic patient
}

\author{
Michael D Weintraub, Thomas C Winter III
}

Radiology and Imaging Sciences, University of Utah, Salt Lake City, Utah, USA

\section{Correspondence to} Dr Thomas C Winter III; tom.winter@utah.edu

Accepted 13 January 2021

\section{DESCRIPTION}

A 49-year-old man with morbid obesity, hypertension and poorly controlled type 2 diabetes mellitus presented to the emergency department with ongoing shortness of breath, leukocytosis of $26000 / \mathrm{uL}$, lactate of $5.6 \mathrm{mmol} / \mathrm{L}$ and positive urinalysis. Serum creatinine was elevated to $5.9 \mathrm{mg} /$ $\mathrm{dL}$, above a baseline of $1.6 \mathrm{mg} / \mathrm{dL}$. CT scan of the abdomen and pelvis without intravenous or oral contrast demonstrated gas replacing the majority of the left renal parenchyma, tracking inferiorly into the proximal left ureter (figure 1, white arrowhead), with two adjacent subcentimeter stones in the distal ureter (figure 2, white arrow). An emergent left radical nephrectomy was performed. Microscopic analysis of the surgical specimen demonstrated acute pyelonephritis with extensive necrosis and minimal viable tissue. Intraoperative cultures grew Klebsiella pneumoniae. The patient was discharged home in stable condition on postoperative day 6 to complete a course of culture-specific antibiotics. $\mathrm{He}$ was last seen in follow-up 5 months from surgery by his primary care provider and was doing well.

Emphysematous pyelonephritis is an aggressive necrotising renal infection, seen predominantly in diabetics. It is caused by gram-negative gasforming organisms, most commonly Escherischia coli, as well as Klebsiella and Proteus species. ${ }^{1}$ It is a urologic emergency that carries high morbidity and mortality. CT is highly accurate for diagnosis. A radiologic classification system based on CT findings may help guide treatment. ${ }^{2}$ In this scheme, when there is viable renal parenchyma, first-line therapy consists of antibiotic therapy, fluid resuscitation, and glycaemic control, with percutaneous renal drainage, with or without ureteral stenting, usually performed as well. ${ }^{3}$ While favourable

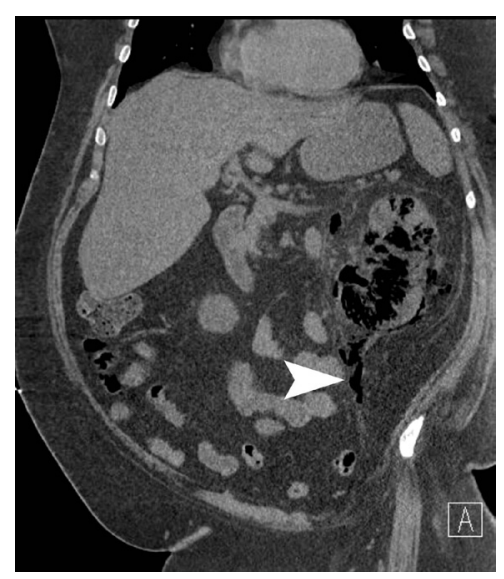

Figure 1 Coronal non-contrast-enhanced image through the abdomen demonstrates diffuse gas within the left renal collecting system and ureter (arrowhead).

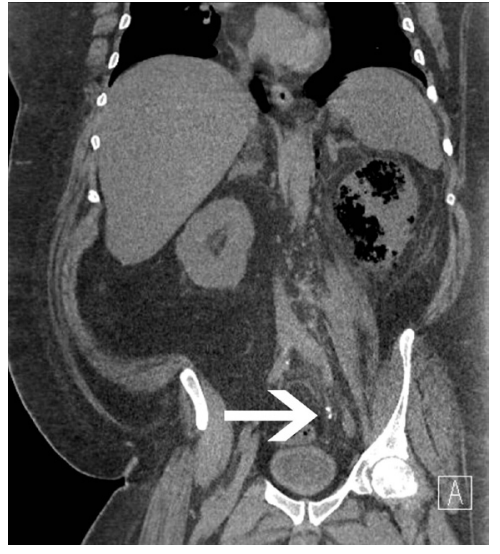

Figure 2 Coronal non-contrast-enhanced image through the abdomen at a level slightly posterior to figure 1 redemonstrates diffuse emphysema of the left renal collecting system as well as two small obstructing stones in the distal ureter (arrow), with marked associated periureteral inflammatory fat stranding.

outcomes have been reported with non-invasive therapy alone, ${ }^{4}$ studies demonstrate significantly decreased mortality in patients treated with percutaneous drainage. ${ }^{5}$ In the setting of diffuse and severe infection, with findings of extensive parenchymal destruction on CT and/or absence of functional kidney demonstrated on nuclear medicine renography, or when there is a failure to respond to first-line treatment, nephrectomy may be indicated. $^{136}$

\section{Learning points}

Emphysematous pyelonephritis is a lifethreatening infection seen in patients with diabetes and is caused by gas-forming organisms such as Escherichia coli and Klebsiella and Proteus species.

- It is an emergency that requires prompt management with antibiotics, fluid resuscitation, glycaemic control, and percutaneous drainage, with possible ureteral stenting. Nephrectomy may be required in severe cases.

Contributors MDW collected the images and clinical data for the case report. TCWI edited the images. MDW and TCWI drafted the manuscript.

Funding The authors have not declared a specific grant for this research from any funding agency in the public, commercial or not-for-profit sectors.

Competing interests None declared.

Patient consent for publication Not required. 
Provenance and peer review Not commissioned; externally peer reviewed.

\section{REFERENCES}

1 Cooper KL, Badalato GM, Rutman MP. Infections of the urinary tract. In: CampbellWalsh urology. 12 edn. Philadelphia, PA: Elsevier, 2021: 1129-201.

2 Huang JJ, Tseng CC. Emphysematous pyelonephritis: clinicoradiological classification, management, prognosis, and pathogenesis. Arch Intern Med 2000;160:797-805.
3 Pontin AR, Barnes RD. Current management of emphysematous pyelonephritis. Nat Rev Urol 2009;6:272-9.

4 Sharma PK, Sharma R, Vijay MK, et al. Emphysematous pyelonephritis: our experience with conservative management in 14 cases. Urol Ann 2013;5:157-62.

5 Somani BK, Nabi G, Thorpe P, et al. Is percutaneous drainage the new gold standard in the management of emphysematous pyelonephritis? Evidence from a systematic review. J Urol 2008;179:1844-9.

6 Saadi A, Ayed H, Bouzouita A, et al. [Results of conservative management of emphysematous pyelonephritis]. Nephrol Ther 2016;12:508-15.

Copyright 2021 BMJ Publishing Group. All rights reserved. For permission to reuse any of this content visit

https://www.bmj.com/company/products-services/rights-and-licensing/permissions/

BMJ Case Report Fellows may re-use this article for personal use and teaching without any further permission.

Become a Fellow of BMJ Case Reports today and you can:

- Submit as many cases as you like

- Enjoy fast sympathetic peer review and rapid publication of accepted articles

Access all the published articles

- Re-use any of the published material for personal use and teaching without further permission

\section{Customer Service}

If you have any further queries about your subscription, please contact our customer services team on +44 (0) 2071111105 or via email at support@bmj.com.

Visit casereports.bmj.com for more articles like this and to become a Fellow 